\title{
Determination and Residues Level of Emamectin Benzoate in Tea Using HPLC with Fluorescence Detection
}

\author{
Madasamy Kottiappan", Shanmugaselvan Veilumuthu Anandham \\ UPASI Tea Research Fondation, Tea Research Institute, Valparai, 642127, TN, India
}

\begin{abstract}
Tea is consumed throughout the world, both for pleasure and therapeutic purpose. Most people will be unaware of their involuntary exposure to residues of pesticide lingering in processed tea and so possibly transferring into infusion of tea. The objective of this trial was not only to provide a simple residue analytical method to evaluate the safe application rate of emamectin benzoate for tea crops but also suitable dosage in tea crop. The residues of emamectin benzoate were determined by high performance liquid chromatography equipped with fluorescence detector. Tea samples extracted with acetone/water $(70: 30 \mathrm{v} / \mathrm{v})$, the extract were cleaned up by liquid - liquid extraction under the fortified level $0.02 \mu \mathrm{g} / \mathrm{mg}$ to 2.0 $\mu \mathrm{g} / \mathrm{mg}$, the recovery ranged from $80.90 \%$ to $115.72 \%$ for black tea, $82.72 \%$ to $106.06 \%$ for sundried green leaves, $83.85 \%$ to $90.64 \%$ for tea brew and $86.33 \%$ to $104.19 \%$ for soil. The limit of detection and limit of quantification of the method were $0.01 \mu \mathrm{g} / \mathrm{mg}$ and $0.02 \mu \mathrm{g} / \mathrm{mg}$.
\end{abstract}

Keywords Emamectin benzoate, Tea, Residues

\section{Introduction}

Teas in India predominantly grow in three different areas Darjeeling, Assam and Nilgiri. India's tea production rose by $10 \%$ to 114.70 million $\mathrm{kg}$ during June, 2011, on the back of higher output in Assam and West Bengal. As an important food crop, there is an important research value on tea pesticide residues.

Emamectin benzoate, a synthetic derivative of abamectin, is 4"- deoxy-4"- (epi-methylamino) avermectin B1 (MAB1) and is a mixture of two active compounds: 4"-deoxy-4"(epi-methylamino) avermectin B1a (MAB1a) and 4"-deoxy4" (epi-methylamino) avermectin B1b (MAB1b). Emamectin benzoate contains the $\mathrm{B} 1 \mathrm{a}$ and the $\mathrm{B} 1 \mathrm{~b}$ analogues in the proportion 9:1 (e.g. Figure 1). The minor structural difference between MAB1a and MAB1b coupled with the preponderance of MAB1a in emamectin benzoate and the nearly identical biological activities of the two homologues indicate that MAB1a can be used as the test substance for emamectin benzoate (e.g.[9]).

Although the residue analysis of emamectin benzoate has been reported in many materials, the literatures were mostly about the multi residue determination method in soils (e.g. [1];[8]), crops (e.g.[12]), fruits and vegetables (e.g.[3]), food stuffs (e.g.[6]), and rice (e.g.[11]). Only few literatures are available with crops, such as Lettuce (e.g.[4]), Cab bage

* Corresponding author:

jey.sub11@gmail.com (Madasamy Kottiappan)

Published online at http://journal.sapub.org/fph

Copyright (C) 2012 Scientific \& Academic Publishing. All Rights Reserved (e.g.[5]), Tomoto, Japanesh radish and Tea (e.g.[13]), rice (e.g.[14]) and Paddy (e.g.[7]). There was neither detailed simple residues analysis method nor residual dynamics report on tea.

Liquid chromatographic method using a UV detector was reported for determining emamectin benzoate residues in crops (e.g.[13]). In this paper a method was developed which involves derivatization using trifluoroacetic anhydride and 1-methyl imidazole and quantification by HPLC equiped with fluorecent detector (FLD).

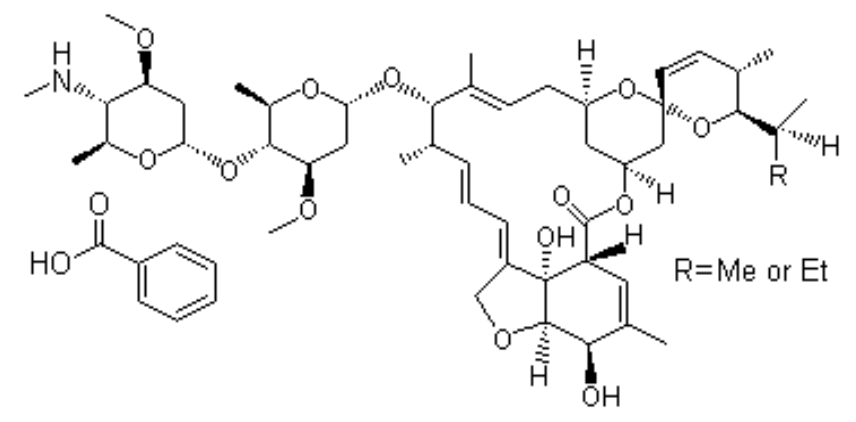

Figure 1. Chemical structure of Emamectin benzoate

\section{Materials and Methods}

\subsection{Field Trials}

Field trials were carried out at two location viz., Valparai and Coonoor (Tamil Nadu, India) situated in 1050 and 1800 $\mathrm{m}$ above MSL respectively. The treatments were consisted of untreated control, recommended dogage and double the recommended dosage. A plot size of 700 bushes for un- 
treated control and each treatment of the pesticide under study, leaving two rows of bushes as guard rows between the untreated control and the different treatment plots was maintained. Emamectin benzoate (Missile 5\% SG) was sprayed at two dose levels, $200 \mathrm{~g} / \mathrm{ha}$ (recommended dose) and $400 \mathrm{~g} / \mathrm{ha}$ (double the recommended dose) with hand operated knapsack sprayer, using a recommended spray volume of $500 \mathrm{~L} / \mathrm{ha}$.

\subsection{Sampling}

For studying the dissipation of emamectin benzoate in tea, samples (two leaves and a bud) were collected at time 0 day ( $3 \mathrm{~h}$ post application, when the spraying mixture had dried) and 1, 3, 5, 7, 10 and 14 days after the application. About 3 $\mathrm{kg}$ of the green tea shoots (two leaves and a bud) were harvested from untreated control and both treatment and brought to the laboratoy.

\subsection{Tea Leaves Processing}

The untreated control and treated green tea shoots from the field were processed in the laboratory's mini manufacturing unit, using a conventional CTC (Crush, Tear and Curl) tea manufacturing process. The manufacturing process, in brief, involved withering of shoots (50-55\% water loss) at ambient temperature for 15-20 h; rolling (twisting and rupturing the tissue to experess the juice) using a rotorvane for about $15 \mathrm{~min}$ with pressure, followed by fermentation (oxidation for $1-2 \mathrm{~h}$ at $25-30^{\circ} \mathrm{C}$ and $95 \% \mathrm{RH}$. Finally, drying in a tea dryer, using hot air at $100 \pm 5^{\circ} \mathrm{C}$, gave tea with final moisture content of $2-3 \%$. The matrices used for residue determinations were the sun dried green leaves, black tea, tea brew and soil.

\subsection{Chemicals}

Technical standard (96.2\% purity) and formulation of emamectin benzoate were received from M/s.Crystal Phosphate Ltd., NewDelhi. Acetone, Dichloromethane, Sodium chloride, anhydrous sodium sulphate of analytical grade and Acetonitrile of HPLC grade were purchased from M/s. Ranbaxy chemicals, NewDelhi. Florisil (60-100 mesh) purchased from M/s. Sisco Research Laboratories, Mumbai. A rotary mechanical shaker (REMI RS 36), a rotary vacuum evaporator (Labserve Super fit PBU6), millipore (Millipore Direct Q3 smart), sonicator and glass column (20 mm dia, $590 \mathrm{~mm}$ ) were also used in this study.

\subsection{Analytical Procedures}

All black tea, sun dried green leaves, tea brew and soil samples were analysed for emamectin benzoate residues by HPLC with fluorescence detector. Extraction, purification and clean-up step are briefly described below.

\subsubsection{Black tea, Sun Dried Green Leaves Extraction and Clean-up Procedure}

Ten grams of black tea/sun dried green leaves sample were extracted with $200 \mathrm{~mL}(100+50+50)$ of acetone: water
$(70: 30, v / v)$ thrice by shaking it in a mechanical shaker for 2 hours. The contents were filtered. The pooled extract was partitioned with $100 \mathrm{~mL}$ of dichloromethane (DCM) and collected the lower organic layer into a $500 \mathrm{~mL}$ round bottom flask (RBF) through anhydrous sodium sulphate. To the separating funnel containing aqueous layer, added $50 \mathrm{~mL}$ of saturated $\mathrm{NaCl}$ and $50 \mathrm{~mL}$ of DCM and shaken vigorously and collected the lower organic layer through anhydrous sodium sulphate into the $500 \mathrm{~mL} \mathrm{RBF}$ and repeated the above steps with another $50 \mathrm{~mL}$ DCM. The combined DCM extract was evaporated to dryness. The concentrated residue is reconstituted an $10 \mathrm{~mL}$ of DCM and transferred to a glass column packed with activated florisil $(10 \mathrm{~g})$ with $1 \mathrm{~cm}$ length of anhydrous sodium sulfate above and below the florisil packing. Prior to elution, the column was washed with $50 \mathrm{~mL}$ of DCM to remove the co-extractives and eluted with 150 $\mathrm{mL}$ of 2:1 acetone and DCM mixture. The collected eluate was concentrated to dryness.

\subsubsection{Tea Brews and Soil Extraction Procedure}

Weighed $2 \mathrm{~g}$ of sample in a cleaned conical flask was adding $100 \mathrm{~mL}$ of boiled water and kept it over a hot water bath for 6 minutes. Filtered the brew and added $100 \mathrm{~mL}$ of DCM and shaken vigorously. Collected the lower organic layer through anhydrous sodium sulphate into $500 \mathrm{~mL} \mathrm{RBF}$ and repeated the above steps twice with another $50 \mathrm{~mL}$ DCM. The pooled DCM extract was evaporated to dryness.

Ten grams of soil sample were extracted with $200 \mathrm{~mL}$ $(100+50+50)$ of acetone: water $(70: 30, \mathrm{v} / \mathrm{v})$ thrice by shaking it in a mechanical shaker for 2 hours. The contents were filtered. The pooled extract was partitioned with $100 \mathrm{~mL}$ of dichloromethane (DCM) and collected the lower organic layer into a $500 \mathrm{~mL}$ round bottom flask (RBF) through anhydrous sodium sulphate. To the separating funnel containing aqueous layer, added $50 \mathrm{~mL}$ of saturated $\mathrm{NaCl}$ and $50 \mathrm{~mL}$ of DCM and shaken vigorously and collected the lower organic layer through anhydrous sodium sulphate into the $500 \mathrm{~mL} \mathrm{RBF}$ and repeated the above steps with another 50 $\mathrm{mL}$ DCM. The combined DCM extract was evaporated to dryness.

\subsubsection{Derivatization}

The emamectin benzoate residue was reconstituted in 10 $\mathrm{mL}$ of acetonitrile and taken $1.5 \mathrm{~mL}$ of this sample solution into a $5 \mathrm{~mL}$ standard measuring flask (SMF). Added $1 \mathrm{~mL}$ of 1-Methyl imidazole: Acetonitile (1:1) and $1 \mathrm{~mL}$ of Trifluoroacetic anhydride: Acetonitrile (1:2). Then the SMF was placed under incubation at $50^{\circ} \mathrm{C}$ for $90 \mathrm{~min}$. After incubation the SMF was cold in an ice bath. The mixture was made acidic by adding $100 \mu \mathrm{L}$ acetic acid and determined emamectin benzoate residue by HPLC with fluorescence detector.

\subsection{HPLC Determination}

Emamectin benzoate residues were determined with Agilent 1100 series equipped with fluorescence detector and 
Zorbax Rx C18 (250 mm x $4.6 \mathrm{~mm}$ x $5 \mu \mathrm{m})$ column. The injection volume was $50 \mu \mathrm{L}$ and column oven temperature maintained at $40^{\circ} \mathrm{C}$. The mobile phase consisted of acetonitrile:water $(95: 5 \mathrm{v} / \mathrm{v})$ and the flow rate was $1.0 \mathrm{~mL} / \mathrm{min}$. The fluorescence detector was operated with emission and excitation wave lengths of $365 \mathrm{~nm}$ and $460 \mathrm{~nm}$ respectively.

\section{Result and Discussion}

\subsection{Emamectin Benzoate Determination Method Efficiency}

The described method of analysis of emamectin benzoate residues in sun dried green leaves, black tea, tea brew and soil by HPLC is fast and relatively simple. Quantification was accomplished by using a standard curve prepared by diluting the stock solution in acetonitrile. A good linearity was achived with a correlation coefficient of 0.9957 . The limit of detection (LOD) was determined, based on the lowest level of standard concentration detected and was found to be $0.01 \mu \mathrm{g} / \mathrm{mg}$. All untreated control samples show no evidence of chromatographic interference in samples of sun dried green leaves, black tea, tea brew and soil. Confirmation of emamectin benzoate in samples was performed by assessing its retention time.The efficiency of the method has been evaluated by spiking sun dried green leaves, black tea, tea brew and soil samples with emamectin benzoate working solutions at various levels $(0.02-2.0 \mu \mathrm{g} / \mathrm{mL})$. Recovery values for black tea, sundried green leaves, tea brew and soil are reported (e.g. Table 1 and 2). All these values of recovery indicated good method accuracy and repeatability, and are within the acceptable range for residue determination.

Table 1. Average Recoveries and Relative Standard Deviation ( \pm RSD) of Fortified Black Tea and Sun Dried Green Leaves samples

\begin{tabular}{ccc}
\hline $\begin{array}{c}\text { Fortification } \\
\text { Level }(\mathrm{mg} / \mathrm{kg})\end{array}$ & $\begin{array}{c}\text { Black Tea } \\
(\%)\end{array}$ & $\begin{array}{c}\text { Sun dried green } \\
\text { leaves }(\%)\end{array}$ \\
\hline 0.02 & $84.57 \pm 0.49$ & $86.08 \pm 5.52$ \\
0.2 & $83.29 \pm 4.05$ & $100.78 \pm 2.27$ \\
2 & $113.69 \pm 2.53$ & $106.05 \pm 0.02$ \\
\hline
\end{tabular}

Values are the average of six replicates

Table 2. Average Recoveries and Relative Standard Deviation ( \pm RSD) of Fortified Tea Brew and Soil Samples

\begin{tabular}{ccc}
\hline $\begin{array}{c}\text { Fortification Level } \\
(\mathrm{mg} / \mathrm{kg})\end{array}$ & $\begin{array}{c}\text { Tea brew } \\
(\%)\end{array}$ & $\begin{array}{c}\text { Soil } \\
(\%)\end{array}$ \\
\hline 0.02 & $89.20 \pm 2.29$ & $86.78 \pm 0.74$ \\
0.2 & $85.15 \pm 0.34$ & $95.11 \pm 7.40$ \\
2 & $86.40 \pm 4.17$ & $103.66 \pm 0.72$ \\
\hline
\end{tabular}

Values are the average of six replicates

\subsection{Dissipation of Residues}

The data relating to the residues in different matrices of tea from the field experiments carried out in September, 2011 (wet season) are reported in Table 3 and 5. No residues of emamectin benzoate were detected in any analysed untreated control tea samples. The initial deposits of the emamectin benzoate residues in black tea at the two different dosages were 0.29 and $0.66 \mu \mathrm{g} / \mathrm{mg}$ in valparai and 0.30 and 0.68 $\mu \mathrm{g} / \mathrm{mg}$ in coonoor. Similarly, In the case of sun dried green leaves, residues observed on day 0 were 0.30 and 0.0 .72 $\mu \mathrm{g} / \mathrm{mg}$ in valparai and 0.0 .32 and $0.74 \mu \mathrm{g} / \mathrm{mg}$ in coonoor. It is evident from the data that emamectin benzoate degraded more rapidly and after 0 day no residues were found in black tea and sun dried green leaves at both dosages. In the tea field, besides the effect of some physical and chemical factors, like light, heat, $\mathrm{pH}$ and moisture (e.g. [10]) might have played a significant role in the degradation of emamectin benzoate residues. There was no detectable residue in soil at both dosages reported in Table 4 and 6.

Table 3. Emamectin Benzoate Residues in Black Tea and Sun Dried Green Leaves at Different Time Intervals after Application in Valparai

\begin{tabular}{|c|c|c|c|c|}
\hline \multirow{3}{*}{$\begin{array}{c}\text { Time } \\
\text { interval } \\
\text { (days) }\end{array}$} & \multicolumn{4}{|c|}{ Emamectin benzoate residue in $\mu \mathrm{g} / \mathrm{mg}$} \\
\hline & \multicolumn{2}{|c|}{ Black tea } & \multicolumn{2}{|c|}{ Sudried green leaves } \\
\hline & $\mathrm{T} 1$ & $\mathrm{~T} 2$ & T1 & $\mathrm{T} 2$ \\
\hline $0^{*}$ & 0.29 & 0.66 & 0.30 & 0.72 \\
\hline 1 & ND & ND & ND & ND \\
\hline 3 & ND & ND & $\mathrm{ND}$ & ND \\
\hline 5 & ND & ND & ND & ND \\
\hline 7 & ND & ND & $\mathrm{ND}$ & $\mathrm{ND}$ \\
\hline 10 & ND & ND & ND & ND \\
\hline 14 & ND & ND & $\mathrm{ND}$ & ND \\
\hline
\end{tabular}

$\mathrm{T}_{1}$ : treatment $1(200 \mathrm{~g} / \mathrm{ha}) ; \mathrm{T}_{2}$ : treatment $2(400 \mathrm{~g} / \mathrm{ha}) ; \mathrm{ND}$ : not detected.

" 3 hours post application, when the spraying mixture had dried.

Table 4. Emamectin Benzoate Residues in Tea Brew and Soil at Different Time Intervals after Application in Valparai

\begin{tabular}{cccccc}
\hline \multirow{2}{*}{$\begin{array}{c}\text { Time inter- } \\
\text { val (days) }\end{array}$} & \multicolumn{3}{c}{ Emamectin benzoate residue in $\mu \mathrm{g} / \mathrm{mg}$} \\
\cline { 2 - 3 } \cline { 5 - 6 } \cline { 5 - 6 } \cline { 4 - 5 } \cline { 5 - 6 } & Tea brew & & \multicolumn{3}{c}{ Soil } \\
\hline $0^{*}$ & ND & ND & & ND & ND \\
1 & ND & ND & & ND & ND \\
3 & ND & ND & & ND & ND \\
5 & ND & ND & & ND & ND \\
7 & ND & ND & & ND & ND \\
10 & ND & ND & & ND & ND \\
14 & ND & ND & & ND & ND \\
\hline
\end{tabular}

$\mathrm{T}_{1}$ : treatment $1(200 \mathrm{~g} / \mathrm{ha}) ; \mathrm{T}_{2}$ : treatment $2(400 \mathrm{~g} / \mathrm{ha}) ; \mathrm{ND}$ : not detected.

3 hours post application, when the spraying mixture had dried.

Table 5. Emamectin Benzoate Residues in Black Tea and Sun Dried Green Leaves at Different Time Intervals after Application in Coonoor

\begin{tabular}{|c|c|c|c|c|}
\hline \multirow{3}{*}{$\begin{array}{c}\text { Time } \\
\text { interval } \\
\text { (days) }\end{array}$} & \multicolumn{4}{|c|}{ Emamectin benzoate residue in $\mu \mathrm{g} / \mathrm{mg}$} \\
\hline & \multicolumn{2}{|c|}{ Black tea } & \multicolumn{2}{|c|}{ Sudried green leaves } \\
\hline & $\mathrm{T} 1$ & $\mathrm{~T} 2$ & $\mathrm{~T} 1$ & $\mathrm{~T} 2$ \\
\hline $0^{*}$ & 0.30 & 0.68 & 0.32 & 0.74 \\
\hline 1 & ND & ND & ND & ND \\
\hline 3 & ND & ND & ND & ND \\
\hline 5 & ND & ND & ND & ND \\
\hline 7 & ND & ND & ND & ND \\
\hline 10 & ND & ND & ND & ND \\
\hline 14 & ND & ND & ND & ND \\
\hline
\end{tabular}

$\mathrm{T}_{1}$ : treatment $1(200 \mathrm{~g} / \mathrm{ha}) ; \mathrm{T}_{2}$ : treatment $2(400 \mathrm{~g} / \mathrm{ha}) ; \mathrm{ND}$ : not detected. 3 hours post application, when the spraying mixture had dried. 
Table 6. Emamectin Benzoate Residues in Tea Brew and Soil at Different Time Intervals after Application in Coonoor

\begin{tabular}{|c|c|c|c|c|}
\hline \multirow{3}{*}{$\begin{array}{c}\text { Time } \\
\text { interval } \\
\text { (days) }\end{array}$} & \multicolumn{4}{|c|}{ Emamectin benzoate residue in $\mu \mathrm{g} / \mathrm{mg}$} \\
\hline & \multicolumn{2}{|c|}{ Tea brew } & \multicolumn{2}{|c|}{ Soil } \\
\hline & $\mathrm{T} 1$ & $\mathrm{~T} 2$ & $\mathrm{~T} 1$ & $\mathrm{~T} 2$ \\
\hline $0^{*}$ & ND & ND & ND & ND \\
\hline 1 & ND & ND & ND & ND \\
\hline 3 & ND & ND & ND & ND \\
\hline 5 & ND & ND & ND & ND \\
\hline 7 & ND & ND & ND & ND \\
\hline 10 & ND & ND & ND & ND \\
\hline 14 & ND & ND & ND & ND \\
\hline
\end{tabular}

$\mathrm{T}_{1}$ : treatment 1 (200 g/ha); $\mathrm{T}_{2}$ : treatment 2 (400 g/ha); ND: not detected.

3 hours post application, when the spraying mixture had dried.

The transfer of emamectin benzoate residue from made tea to tea brew was observed, there was no detectable residue tranfer to the tea brew at both dosages reported in Table 4 and 6. This indicated that the emamectin benzoate has low water solubility, $0.024 \mathrm{~g} / \mathrm{L}\left(\mathrm{pH} 7,25^{\circ} \mathrm{C}\right)$. Thus, tea brew consumption is safe at the normal harvesting interval after treatment.

\section{Conclusions}

The described method of analysis of emamectin benzoate residues is suitable for determination of residues in tea and the method can be suitably applied to the other crops. It is suggested that the data on leaching of residues into tea brew should be taken into account for fixing a realistic MRL for pesticides in black tea.

\section{ACKNOWLEDGEMENTS}

We acknowledged the support and grants from UPASI Tea Research Institute, Valparai and M/s. Crystal Phosphate Ltd., NewDelhi.

\section{REFERENCES}

[1] Amechi, C. C., William, F. F., Thomas, J. B., Louis, S. C. and Peter, G. W., 1996, Uptake of emamectin benzoate residues from soil by rotational crops. Journal of Agriculture and Food Chemistry, 44, 4015-4021.

[2] Amechi, C. C., 1997, Metabolic fate of emamectin benzoate in soil, Journal of Agriculture and Food Chemistry, 45, 4137-4146.

[3] Ceshing, S. and Hui-Chi, C., 2009, Simultaneous determination of macrolide pesticides in fruits and vegetables by liquid chromatography, Journal of Food and Drug Analysis, 17, 198-208.

[4] Crouch, L. S. and Feely, W. F., 1995, Fate of $\left[{ }^{14} \mathrm{C}\right]$ emamectin benzoate head lettuce, Journal of Agriculture and Food Chemistry, 43, 3075-3087.

[5] Crouch, L. S., Wrzesinski, C. L. and Feely, W. F., 1997, Fate of $\left[{ }^{14} \mathrm{C}\right]$ emamectin benzoate in cabbage. 1. Extractable residues, Journal of Agriculture and Food Chemistry, 45, 2744-2757.

[6] Giannetti, L., Giorgi, A., Necci, F., Ferretti, G., Buiarelli, F. and Neri, B., 2011, Validation study on avermectin residues in foodstuffs, Analytica Chimica Acta, 700, 11-15.

[7] Minghui, L., Weitao, C., Mengyi, L. and Lijun, H., 2011, Dissipation and residues of emamectin benzoate study in paddy under field conditions, Journal of bulletin Environmental Contamination and Toxicology, 87, 699-702.

[8] Mohammad, M., William, F. F., Loretta, R. S. and Peter, G. W., 1996, Immobility of emamectin benzoate in soils, Journal of Agriculture and Food Chemistry, 44, 940-944.

[9] Shoop, W. L., Mrozik, H. and Fisher, M. H., 1995, Structure and activity of avermectins and mibemycins in animal health, Veterinary Parasitology, 59, 139-156.

[10] Tewary, D. K., Ravindranath, V. K. and Shanker, A., 2005, Dissipation behavior of bifenthrin residues in tea and its brew, Food Control, 16, 231-237.

[11] Xie, X., Gong, S., Wang, X., Wu, Y. and Zhao, L., 2011, Simplified RP-HPLC method for multi-residue analysis of abamectin, emamectin benzoate and ivermectin in rice, Food additives and Contamination, 28, 19-25.

[12] Yoshii, K., Kaihara, A., Tsumura, Y., Ishimitsu, S. and Tonogai, Y., 2000, Liquid chromatographic determination of emamectin, mibemectin, ivermectin and abamectin in crops and confirmation by liquid chromatography-mass spectrometry, Journal of Chromatography A, 896, 75-85.

[13] Yoshii, K., Ishimitsu, S., Tonogai, Y., Arakawa, K., Murata, H. and Mikami, H., 2004, Simultaneous determination of emamectin, its metabolits, milbemectin, ivermectin and abamectin in tomato, japanesh radish and tea by LC/MS, Journal of Health Science, 50(1), 17-24.

[14] Zhang, K. K., Hu, D., Zhang, Y., Lu, P., Zeng, S., Song, B., Huang, R. and Guo, Q., 2010, Residue and decline study of emamectin benzoate in rice field, Chinese Journal of Pesticide Science, 12(2), 190-194. 